\title{
Selecting Motivating Repertoire for Adult Piano Students: A Transformative Pedagogical Approach
}

\begin{abstract}
Selecting repertoire that adult piano students find motivating and musically satisfying is more complex than simply finding pieces that are aurally pleasing. Drawing on theories of motivation, adult learning and transformative pedagogy, this practitioner-based study describes how the author learned to involve her students in the selection process, to align repertoire with their tastes and goals, and to understand the impact of students' values, expectations and perceptions of learning on their engagement with repertoire learned. It is hoped that the experiences and theories shared herein inspire teachers to reflect on their own pedagogical choices regarding repertoire selection.
\end{abstract}

Key words: Repertoire selection, piano pedagogy, transformative pedagogy, adult piano students, adult learning theories, motivation.

Over the last few decades, with the expanding population with more expendable income, more time (in the case of retirees), and an increased desire and opportunity to fulfil childhood dreams (Jutras, 2006), the number of adults seeking piano lessons has increased across the Western world. As such, many one-to-one studio piano teachers have diversified their teaching to include adult novices (Uszler \& Upitis, 2000). Retaining adult novices long term, however, is notoriously difficult (Bowles, 2010). The majority of studies exploring adult piano students to date have thus sought to understand their demographics, motivations for learning, and perceived benefits gained from piano tuition (see Cooper, 2001; Jutras, 2006; Swenson 2006; A. Taylor, 2011; A. Taylor \& Hallam, 2008; Thornton, 2010; Wristen, 2006). Their rationale is that if we understand both who adult students are, and what they want, we as teachers can adapt lessons accordingly, potentially helping to retain students long term. This qualitative study adds to this body of knowledge from a practitioner perspective. Specifically, it explores how theories of motivation, adult learning and transformative pedagogy can inform repertoire selection with adult students. As adult students often cease lessons due to a dislike of repertoire learned (Wristen, 2006), it focuses on the processes involved in selecting repertoire that is both motivating and musically satisfying.

\section{Motivation and the Adult Piano Student}

Motivation is the product of the value a student places on the pursuit or task and a student's self-efficacy level (Schunk, 2012). The value of a task depends on its relevance to the student's goals, as well as the perceived benefits reaped. Two 
predominant benefits often sought by adult piano students are personal benefits, such as personal growth, challenge, enjoyment and dream fulfilment, and skill development, including musical and technical growth at the instrument (Cooper, 2001; Jutras, 2006; Wristen, 2006; E. W. Taylor, 2008; A. Taylor, 2011). These benefits may be interrelated, with personal benefits, such as enjoyment, being somewhat dependent on skill development (Wristen, 2006; Jutras, 2006).

Self-efficacy - the belief about one's ability to learn or perform a task effectively - is a key internal factor of motivation, as it affect's one's actions, choice of tasks, persistence, effort and ultimately their achievement as a result (Schunk, 2012). It includes a student's expectancy for success, judgement of ability, and confidence in their skills (Duncan \& McKeachie, 2005). As Schunk (2012) explains, 'people who believe they can perform better persist longer and work harder' (p. 127). They also experience fewer negative emotions surrounding slow progress (Kitsantas, Reiser \& Doster, 2004). Bugos and High (2009) note that self-efficacy within the context of piano practice is influenced by attitude, achievement and coordination. These insights further highlight the interconnected nature of mind-sets and skill development, which ultimately also affect students' abilities to reap their sought-after benefits (Zimmerman \& Schunk, 2012). In relation to repertoire, self-efficacy relates to the levels of challenge a piece presents. If self-efficacy levels are low, even if a piece is aurally pleasing, motivation may be adversely affected. High self-efficacy has been noted as fundamental for those learning a musical instrument, as it relates to sustained music practice (McCormick \& McPherson, 2003) and use of deliberate practice strategies (Bugos \& High, 2009), resulting in engaged learning at the instrument (Nielsen, 2004).

The discontinuous model of motivation serves as an appropriate model from which to understand motivation in this context as it focuses on task value and selfefficacy levels as main determinants of behaviour (Vancouver, More \& Yoder, 2008). This model is outlined in Figure 1 [INSERT FIGURE 1 NEAR HERE - figure and caption supplied at the end of this document and as separate TIFF file].

From a musical perspective, MacDonald, Hargreaves and Miell (2012) argue that the expectancy-value theory is the most well-established and useful theoretical approach from which to examine motivation. This model encompasses a range of assumptions regarding the relationships between self-efficacy and value:

- The greater the difficulty, the greater the reward;

- The greater the reward, the greater the level of effort required to obtain that reward;

- The greater the reward, the greater the desire to put in the effort to obtain that reward;

- These factors have a limit; if success is felt to be unachievable, one will not try (Vancouver, More \& Yoder, 2008).

The peak of the $\mathrm{Y}$ axis can be viewed as aligning with Csikszentmihalyi's $(1991 ; 2000)$ concept of flow, whereby someone is completed absorbed in the task at 
hand. This optimal state of experience occurs when intrinsic motivation is high. As with the discontinuous model depicted above, it has been found that for adult music students, mental distractions and minimal growth potential inhibits the ability for students to achieve the flow state, or the optimal state for learning. If perceived task value is low, or if the difficulty is deemed too great, the flow state will not be entered into (Rybak, 1995). It is thus important as teachers to understand how we might capitalise on and flame students' intrinsic motivation.

Theorists (Bomia et al., 1997; Keller, 2009) offer pedagogical principles based on the assumptions built into the discontinuous model of motivation. They recommend that teachers:

- increase students' involvement in repertoire selection through choice and growing autonomy;

- provide opportunities for success to build self-efficacy;

- discuss benefits of repertoire to increase value.

These recommendations align with transformative pedagogy (Carey \& Grant, 2016; Carey et al., 2013), which also emphasises the need for a teacher to collaborate with the student in every aspect of their learning. It acknowledges the student as a whole, including their histories, frames of reference, mindsets, goals and values. As such, it is advised that teachers are empathetic, build rapport with their students, and provide an environment in which they feel safe to participate freely without fear of judgement (Jarvis, 2010). Rather than simply assigning repertoire for students to learn based on the teacher's perceptions of students' needs and skillsets, transformative pedagogy requires a teacher to spend more time learning about their students' goals and musical tastes.

While piano pedagogues also encourage teachers to align repertoire with adult students' musical tastes, interests and goals (Uszler \& Upitis, 2000; Cooper, 2001; Jutras, 2006; Wristen, 2006), many piano teachers feel ill-prepared to accommodate the self-defined and specific goals of individual adult students, and feel frustrated at the need for flexible learning plans (Bowles, 2010). This study, thus, aims to uncover potential strategies to overcome this frustration and how they might unfold within the context of one-to-one piano lessons. The methodology and research design is offered below, before turning to a discussion of the experiences and learning outcomes obtained from the study.

\section{Research Design}

This study was part of a larger research project that aimed to better facilitate all aspects of adult learning at the piano, through understanding repertoire selection, lesson interactions and home practice [de-identified for review purposes]. The aim of this specific study was to learn how to engage students with their learning through the selection of motivating and relevant repertoire. Given the prior discussion on 
motivation, relevance for this purpose is multifaceted. It not only relates to goals and musical tastes, which are easily made explicit, but also depends on a student's internal processes and perceptions, such as self-efficacy and the importance an individual places on certain benefits and values (Vancouver, More \& Yoder, 2008; Keller, 2009; Weiner, 2010). It thus extends beyond aligning content learned with a student's tastes and goals, to include maximising the perceived value of materials learned and balancing this with students' perceptions of their ability to succeed at tasks.

\section{Methodology}

As I am a piano teacher with adult piano students, and given that the aim of this study was both a conceptual and practical one, it was most appropriate to use a practitionerbased methodology (Lankshear \& Knobel, 2004; Leiper, 2012). This allowed me to not only explore theories of adult learning and motivation, but also to implement resultant strategies within the context of my own one-to-one piano studio. While the experiences shared herein are unique to the context of my studio and students, it is understood by the educational community that much can be learned from the unique experiences of individuals (Ellis \& Bochner, 2000; Flyvbjerg 2006; Richardson, 1994;) and that the practical wisdom of teachers has an important role in informing pedagogical strategies (Gelder, 2005, p. 41).

\section{Participants}

The participant pool for this study included the adult piano students within my piano studio. As I was affiliated with [de-identified for review purposes] university, I followed standard procedures of their Human Ethics Committee and received approval prior to commencing this study. While the student-teacher power relationship was something to be mindful of (Lankshear \& Knobel, 2004), this was addressed through an open and respectful research design that focussed on evening the power relationship through transformative strategies. Of the twelve adults invited, six chose to participate. Four of these students who represent a range of scenarios and challenges in relation to engagement with repertoire have been chosen for this discussion. Table 1 [INSERT TABLE 1 NEAR HERE - figure and caption supplied at the end of this document and as separate TIFF file] offers details of each student's demographics, musical level, musical tastes and musical aspirations. Student identities are protected through the use of pseudonyms.

As evidenced in this table, student participants have a variety of musical tastes and aspirations, which is representative of a standard private piano studio. There are two notable similarities, however. Firstly, they each wished to work towards advanced repertoire or a high level of competency at the piano. Secondly, their aspirations for the future of their playing aligned with their current musical tastes. This strengthens the argument for honouring adults' specific musical tastes and goals (Wristen, 2006; Bowles, 2010) when selecting repertoire.

\section{Data generation and analysis}

This study was conducted over a nine-month period, from June 2013 to February 
2014. Over this time, several sources of data were generated: video recordings of lessons, a reflective weekly teaching journal, and pre- and post- study interviews with student participants. Data generation was cyclic, with weekly reflections informing lessons and lessons informing reflections. These reflections also drew on interview responses and were informed by the literature surrounding adult learning and motivation. Data sets, whilst informing my weekly pedagogical decisions and teaching actions, were analysed discretely at the conclusion of the study, before being triangulated for common themes. Themes of relevance and self-efficacy served as a starting point for deductive analysis. Sub-themes emerged inductively, before being analysed according to the discontinuous model of motivation outlined previously (see Figure 1).

\section{Context: My Original Pedagogical Framework for Repertoire}

\section{Selection}

Prior to this study, I thought it was a teacher's job to ensure all students, regardless of age, were exposed to, and learned, a broad spectrum of musical styles. I believed that this resulted in a well-rounded music education. What I found, however, was that my adult students would inevitably practise the pieces they liked and were aurally familiar with, and would make excuses for not practising the pieces that sounded less familiar. While I chose to abandon this quest to foster diverse musical tastes at the outset of this study, there were other pedagogical decisions in relation to repertoire selection that I felt was important to maintain. Questions I asked myself included:

- Is the piece at an appropriate difficulty level?

- Does the piece provide opportunities to consolidate prior knowledge and skills as needed?

- Does the piece build on prior knowledge and skills and provide opportunities for scaffolding?

These objectives rely on my perceptions of students' needs rather than theirs. Finding repertoire that adhered to these pedagogical principles, while also matching students' goals and perceived needs, was challenging. The adaptations that I learned to make, as well as the insights into student motivation and needs are discussed below.

\section{Relevance Determined by External Goals}

Prior to the study, Derek expressed the desire to sit exams. As this is an external goal with a predetermined framework, the appropriateness of the materials to his goals was unquestioned. Repertoire selection simply involved presenting Derek with a couple of pieces that I felt were appropriate for the musical concepts we were exploring at the time, and asking him to choose the one he preferred. Derek was happy to be led and did not display a preference for those I presented him with. The main challenge we faced was Derek's expectation to learn his pieces quickly and with little effort. 
When Derek first started lessons three months prior to the study, he completed pieces quickly and received several small pieces each week. This was in part because I was discovering his capabilities and also because I felt that this was conducive to offering opportunities for success that could build confidence and thus fuel motivation (A. Taylor \& Hallam, 2008). Unfortunately, this inadvertently gave him a false sense of security. Unbeknown to me, Derek had started lessons expecting playing to be easy, and his early experiences had strengthened this perception. While I took his early successes as an opportunity to provide greater challenges and for him to be ready to start preparing for his first exam, he saw challenge as a sign of weakness and was taken aback at how difficult he found it (Dweck, 2007). As Bohlin et al. (1993) suggest, requirements for success need to be clear to the student, along with relevance to the student's goals and the benefits of pieces learned. As such, we had discussions around his readiness for exam preparation, and the time frames to be expected for learning these more challenging pieces. I continued to offer smaller supplementary pieces that could help to reinforce concepts, but Derek neglected these in favour of the exam pieces, highlighting that those that appeared more relevant to his goals were more enticing, despite their comparative difficulty (Vancouver, More \& Yoder, 2008).

While an external framework made repertoire selection straightforward for Derek, this external structure did not exist for other students. This created the opportunity for them to be more involved in the process of sourcing and selecting repertoire. While some pedagogues claim that selecting repertoire is one of the most important tasks a teacher has (Uszler \& Upitis, 2000; McAllister, 2008), others posit that allowing students to choose their own repertoire would provide added motivation to practice (Lehmann et al., 2007) and contribute to their sense of self-fulfilment (A. Taylor \& Hallam, 2008). Increasing student autonomy, however, presented a challenge; ensuring repertoire was pedagogically appropriate for their current ability level.

\section{Creating Our Own Framework}

Many adult students' musical tastes tend to lean towards music that is much more sophisticated than their current skills and experience, and this was evident with my students. As a learner's perceived and actual needs may not be congruent (Keller, 2009), it is important for the teacher to consider the difficulty level of repertoire learned in order to avoid frustration and adversely affecting the learner's confidence (Jutras, 2006). The optimum level of challenge — not too easy to invoke boredom, nor too hard to create anxiety, and requiring effort to master - can help to increase selfefficacy as students overcome challenges just beyond their current skill level (Maehr et al., 2002). For this reason, teachers cannot simply leave choice of repertoire to students; support, guidance and discussions are required. How this unfolded with Cathryn and Anne depended on their unique perceptions of their learning and abilities. 


\section{Perceptions of ease and lack of commitment}

Cathryn had learned piano as a child and thus had a good musical foundation and skillset. She also has highly formed musical tastes and arrived at lessons with a strong desire to focus on technical skill and mastery in order to play the pieces that inspire her. Given her strong intrinsic motivation and the fact that she was not a beginner, she had a lot of freedom in relation to her repertoire choices. I gave Cathryn repertoire lists and asked her to listen, mark ones that she liked, explore other pieces, and make her own suggestions so that we could discuss them in her lessons. While Cathryn's tastes led her to more advanced repertoire, I encouraged a focus on some of the less sophisticated pieces. Cathryn understood the benefits of this, commenting in her initial interview:

A little piece is nice because I can then at least get it in my head and have the whole thing there and can then work on the overall feelings of the piece without having to worry about the notes being wrong.

In practice, however, Cathryn's motivation to focus on these pieces was low, resulting in inconsistency in the repertoire she would bring to her lessons each week. In her interview, I reminded Cathryn of a conversation in our lesson together two weeks prior, where she had said, 'I know I need time on it to do it, but if I put the time in, I know I'll be able to do it, so I don't bother' (lesson conversation, July, 2013). This highlights how perceptions of ease can adversely affect motivation, as there is little perceived value in the task (Vancouver, More \& Yoder, 2008; Schunk, 2012).

Cathryn also provided an alternative perspective in her interview:

But it's interesting, because... maybe I'm not that confident that I can get piano to where I want it to be yet. Like, I'm never really happy with a piece and not necessarily confident that I can get it to where I think it should be.

This fear of disappointing herself was a sign of potentially having low selfefficacy in relation to achieving standards with which she can feel satisfied. Interestingly, it was also in direct contrast to her perceptions of ease. This highlights the power of expectations. Cathryn expected that if she tried, she would be able to play the piece. Fear that she would not live up to those expectations stopped her from trying. This led to a challenge of consistency in relation to her repertoire, which was compounded by the freedom I granted her.

\section{Inspiring aural output increasing motivation to commit}

Four months into the study, Cathryn was regularly suggesting some advanced repertoire that she was inspired to learn. I decided to honour Cathryn's wishes and to explore the repertoire she brought to her lesson. We chose a piece approximately two grades higher than her current skill level. This not only satisfied her need for a sense of challenge and progress, but was also at a level where she did not have preconceived expectations of 'ease' that could inadvertently affect her motivation. Cathryn thus worked consistently on this piece for the remaining five months of the 
study. This supports the theory that an increase in difficulty can increase the value for the student in such a way that increases the drive to sustain focus and effort (Schunk, 2012).

Cathryn was not the only student who placed more value on challenge than completing pieces. Anne also valued challenge, but her perceptions around her learning impacted her in different ways.

\section{Perceptions of difficulty, progress and challenge}

Anne often expressed the desire to sound as 'fluid and beautiful' as me and to command the piano with my apparent ease. A challenge of Anne's, however, was that she focused predominantly on learning the notes and rhythm of her pieces without placing great emphasis on details of articulation and expression. This meant that she felt ready to move to new repertoire before developing the expressive skills that would help her to achieve that goal. Like Cathryn, she also wished to learn pieces that I felt were outside of her current abilities. Learning new notes gave Anne more satisfaction and enjoyment than working towards her peripheral goal of achieving fluency and expression. She explained, 'I love working out a new piece. As soon as you give me a new piece, I end up focusing on that instead of polishing up my other pieces' (lesson conversation, November, 2013).

One of the reasons for Anne's resistance to spending more time on technical and musical skills was her fear that being in her seventies meant that her fingers were 'too old' to develop beyond their current level. She explained in her initial interview:

I sometimes think my fingers aren't quick enough to go past where they're at... Being old, you know... I just think my golf is slowly going down the tube and I think, you know, you're really not as good physically as you get older. I used to be able to hit the ball a lot further. And that's much the same thing... I hope I can get my fingers working.

While technical facility at the piano is potentially hindered by such ailments as arthritis for older adults (Wristen, 2006), Anne does not suffer from such conditions. This is an example of how attribution to age, which is out of a student's control, can adversely affect self-efficacy levels (Jones, 2009; Weiner, 2010). For Anne, this created a lack of desire to focus on expressive details. Despite perceived physical limitations, being mentally active into old age was a high priority for Anne, which she attributed to learning new and challenging notes. Unlike her perception of age, she felt this was something that she had control over and could develop, making her desire more challenging pieces.

When a student's musical tastes are beyond their playing ability, Maris (2000) explains that compromise is needed. This requires both teacher and student to work together to find a suitable piece that fulfils the student's desire for pleasurable pieces, and considerations of pedagogical appropriateness. Anne and I started spending more time in lessons exploring repertoire options together that would satisfy both our needs. This use of time in lessons was difficult for me initially, as I felt that lessons 
should be a time for learning repertoire, not deciding what to learn. Seeing Anne's enthusiasm for doing this together in lessons, however, made me realise that she saw value in this interaction. It allowed us to discuss goals, values and what we were both looking for in a piece, revealing our inconsistent perspectives and enabling us to work towards a common ground.

Through our conversations I realised that I would have to let go of my desire for Anne to focus on musical expression and to fuel Anne's motivation by moving on to larger works. Anne readily sourced the pieces herself, illustrating how aligning repertoire with students' tastes and goals can increase their desire to take ownership of repertoire selection. While she did not have the technical facility to learn these to the required tempo or with great flow or ease, they fulfilled her desire for challenge and were a style that she loved. As such, she felt great satisfaction in learning them. She commented in her interview, 'I really love doing the Mozart sonata. I adore practising it; I really enjoy it. And this last little section, as much as it's driving me nuts, I'm going to get it!' This sign of determination to work through the challenges illustrates Anne's sustained motivation to finish the piece.

We also worked to address Anne's problematic associations with age; regularly exploring how musical expression is linked to learned technical skills and effort. I assured her that we could break those down into manageable and controllable strategies (Jones, 2009; Keller, 2009; Weiner, 2010). This gradually had a positive impact on the expressive focus she gave to her pieces, especially for the more complex pieces she placed great value on learning. At the end of the study I asked Anne whether she still felt she had reached the ceiling of her ability. She responded, 'But then you gave me strategies, didn't you? In how to move my hands. So I started practising those and I can see the ceiling moving a little bit further up' (interview with Anne). With discussions and strategies, Anne's unhelpful perceptions started to shift, illustrating their ability to be transformed over time (Mezirow, 1991; MacDonald et al., 2012).

In the case of both Cathryn and Anne, increasing the difficulty of their repertoire increased the task's perceived value and thus increased their motivation to expend the effort required to learn them (Vancouver, More \& Yoder, 2008). As they regarded their pieces as challenging and requiring effort, self-efficacy issues due to unrealistic expectations lessened, allowing them to commit to these pieces for longer than they had with smaller pieces.

Repertoire selection discussed thus far has been with students who shared my love of classical music. This was not the case for one student, Graham, whose love of 1920 s to 1950 s jazz was quite removed from my own classical musical world. I chose to abandon my comfort zone completely with Graham and worked with him to find a new structure to honour his musical tastes and goals. 


\section{Collaboration and Relying on a Student's Prior Knowledge}

Prior to this study I used the fact that Graham was a novice to choose pieces that I was familiar with. I remember thinking, Surely any music is good for him to learn the foundations of technique and reading? Graham obligingly agreed with my decisions, acknowledging that they were all helping to develop his reading and playing skills. As time went on, however, my repertoire choices started to play on my mind as Graham frequently told me about the music he loved so much. I thought to myself, I wish I knew how to find repertoire he would actually enjoy. I don't know anything about teaching jazz.

As Graham's ability increased over our first two years together, we moved from adult method books and books that I was familiar with to popular pieces from books with dubious (to me) titles such as Easy Piano-50 Best Songs of All Time. While he was at least learning pieces that he was familiar with and enjoyed, my unease continued to grow. This book isn't pedagogically sound. Where is this leading? I'm not sure I'm up to this. I attempted to expand my knowledge of available jazz repertoire, introducing pieces from modern jazz composers that were part of the AMEB syllabus. Graham was happy to learn whatever I gave him, but commented that they were far from the styles that he loved so dearly.

In Graham's initial interview, I became aware that he owns a wealth of music books full of the songs he loves. Graham brought some of his home library to his first lesson of the study as a springboard for creating a plan. These books were arranged for piano, voice, and guitar and were too advanced for Graham's current ability. One of the challenges I faced was that there are not necessarily method books or pedagogically sound repertoire books that meet the specific tastes of each adult student. This was the case for Graham's love of the stride and walking bass arrangements of jazz standards. In order to fully commit to sharing Graham's desired path with him, I realised this meant manipulating the materials we had for our needs.

As well as advanced arrangements, Graham also had folders full of lead sheets. I wondered whether creating our own arrangements would be a feasible way forward. At this point Graham already had a fundamental understanding of chords and the compositional techniques used in these pieces, and so we could use his knowledge in this area to our advantage. This did, however, lead to some challenges.

\section{Unrealistic comparisons}

Initially Graham's arrangements were complex and busy. He had been arranging his music in the typesetting program Finale, away from the piano. While being familiar with Finale was an advantage, it was also problematic because when at the piano Graham could not handle the arrangements he had created. In our lessons, Graham frequently explained how his idols played and how he was trying to emulate them.

In his initial interview, Graham commented:

I suppose in your heart of hearts you still aspire to be up amongst those greats 
really. That's - you know, we've all got goals, and sometimes they're very utopian... the hard thing is always that the stepping stones are sometimes somewhat minor and that's how it has to be. And you've got to accept that or come to terms with it.... What makes me more fearful... is the challenges that still lie ahead, really. Trying to master what's coming. And that is somewhat a frightening prospect really.... Wondering whether I have the ability to make that really happen.

We had discussions about starting simply, adding one arrangement and playing skill at a time, but left to his own devices, Graham's arrangements were overly complex as he attempted to, in his words, 'emulate the style of the Greats' (lesson conversation, August, 2013). His large ambitions, plus the acknowledgement of small progress and fear that he may never achieve his goals highlights an internal conflict that was evident in his lessons. We started using lessons to do more arranging together. Experiencing how to simplify with my guidance allowed Graham to understand how to work to his current level rather than using his idols as benchmarks.

This is an example of how the wealth of knowledge adults bring to their lessons can be a powerful resource to draw on in their learning (Knowles et al., 2011). It also illustrates that a student's and teacher's musical backgrounds and tastes do not necessarily have to be aligned in order for the student to learn music that is meaningful to him.

\section{Learning Outcomes and Conclusions}

The fundamental value underpinning a transformative pedagogical approach is the desire to create a reciprocal and interdependent relationship where the student is involved in all choices relating to their learning (E. W. Taylor, 2008). In this way, the relationship between the learner and subject matter becomes the focus (Rinaldo \& Denig, 2009). In relation to deciding upon repertoire to be learned, this means an increase in discussions with students around repertoire selection and musical goals and tastes, and an increase in the time spent exploring options together. This study highlighted some of the ways in which students' expectations and perceptions of their learning abilities can impact on their engagement with the repertoire they learn, and how student-teacher collaboration can address challenges and find solutions that best fit student needs.

To adopt a transformative approach, teachers need to not only prioritise their interpersonal relationships with their students, but also be willing to suspend and reflect on their own expectations and conceptions of learning outcomes and be willing to alter their pedagogical approaches as a result. My initial pedagogical framework, described earlier, relied heavily on my perceptions of my students' needs and current skill level. I learned, however, that it is more important to align repertoire selection with the benefits students seek, rather than the external performative and prescriptive musical skills by which I was accustomed to measuring student learning. 
In order for me to find peace with working outside Cathryn and Anne's comfort zones, I had to abandon the idea that opportunities for success meant completing pieces to certain external standards, which is an extrinsic determinant of success. Success to Cathryn was growing technical facility, and success to Anne was being mentally stimulated and feeling that she was being challenged and thus staying mentally young. These examples of seeking to obtain intrinsic values (Renwick \& Reeve, 2012) show that success on a broader level means to simply reap the benefits the student is seeking in such a way that sustains motivation to continue.

In relation to Graham, I learned to rely on his prior knowledge and resources to find motivating repertoire and create a general plan moving forwards. I could then combine this with my pedagogical knowledge to create a specific plan that was educationally sound. I grew a lot as a teacher through this process, developing skills of teaching beyond the page (Darling, 2005) and learning the true meaning of studentteacher collaboration.

While this study does not purport to be conclusive or prescriptive, it is hoped that the experiences shared demonstrate the possibilities of a transformative pedagogical approach with principles of student motivation at its core. Similarly, it is hoped that teachers are inspired to explore their relevance to their own one-to-one studio practices, potentially learning more about their students while simultaneously increasing students' motivation towards their repertoire.

\section{Acknowledgements}

Thank you to the students who participated in this study for their time and interest and for allowing me to explore and share their learning journeys.

\section{References (to add one removed for review purposes)}

ABRAHAMS, F. (2005). The application of critical pedagogy to music teaching and learning: A literature review. Update: Applications of Research in Music Education, 23, 2, 12-22.

AMIN, A. (n.d.). Goal setting theory. Retrieved from http://happierhuman.com/goalsetting-theory/

BIGGS, J. B. \& TANG, C. (2011). Teaching for quality learning at university $\left(4^{\text {th }}\right.$ ed.). New York, NY: Society for Research into Higher Education and Open University Press, McGraw Hill.

BOHLIN, R. M., MILHEIM, W. D. \& VIECHNICKI, K. J. (1993). The development of a model for the design of motivational adult instruction in higher education. Journal of Educational Technology Systems, 22, 1, 3-17.

BOMIA, L., BELUZO, L., DEMEESTER, D., ELANDER, K., GRAHAMSON, M. \& SHELDON, B. (1997). The impact of teaching strategies on intrinsic 
motivation. ERIC database. Retrieved from http://eric.ed.gov/?id=ED418925

BOWLES, C. L. (2010). Special topics - Teachers of adult music learners: An assessment of characteristics and instructional practices, preparation, and needs. Update: Applications of Research in Music Education, 28, 2, 50-59.

BUGOS, J. A. \& HIGH, L. (2009). Perceived versus actual practice strategy used by older adult novice piano students. Visions of Research in Music Education, 13. 1-26. Retrieved from http://www-usr.rider.edu/ vrme/

CAREY, G. M., BRIDGSTOCK, R., TAYLOR, P., MCWILLIAM, E., \& GRANT, C. 2013. Characterising one-to-one conservatoire teaching: Some implications of a quantitative analysis. Music Education Research 15, 3, 357-368. doi:10.1080/14613808.2013.824954

CAREY G. \& GRANT, C. 2016. Enacting transformative pedagogy in the music studio: A case study of responsive, relational teaching. Paper presented at the ISME CEPROM Seminar, Saint Andrews, Fife, Scotland, 54-63.

CHEN, H. (1996). An investigation of self-directed learning among non-music major adult piano learners in one-to-one piano instruction (Doctoral dissertation). Retrieved from ProQuest Dissertations \& Theses database. (UMI No. 9635962).

CSIKSZENTMIHALYI, M. (1991). Flow: The psychology of optimal experience. New York, NY: HarperPerennial

CSIKSZENTMIHALYI, M. (2000). Beyond boredom and anxiety: Experiencing flow in work and play. San Francisco: CA: Joseey-Bass.

COOPER, T. L. (2001). Adults' perceptions of piano study: Achievements and experiences. Journal of Research in Music Education, 49, 2, 156-168.

DABBACK, W. M. (2003). Toward andragogy in music: Examining the gap between theory and emerging practice in the instrumental music education of older adults. International Journal of Community Music, 2, 1, 1-16.

DARLING, E. (Ed). (2005). A piano teacher's legacy: Selected writings by Richard Chronister. Kingston, NJ: The Francis Clark Center for Keyboard Pedagogy.

DUNCAN, T. G. \& MCKEACHIE, W. J. (2005). The making of the motivated strategies for learning questionnaire. Educational Psychologist, 40, 2, 117128. doi:10.1207/s15326985ep4002_6

DWECK, C. (2007). Mindset: The new psychology of success. New York, NY: Ballantine Books.

ELLIS, C. \& BOCHNER, A. P. (2000). Autoethnography, personal narrative, reflexivity. In N. K. Denzin \& Y. S. Lincoln (Eds.), Handbook of qualitative research (2nd ed., pp. 733-768). Thousand Oaks, CA: SAGE.

FLYVBJERG, B. (2006). Five misunderstandings about case-study research. Qualitative Inquiry, 12, 2, 219-245. doi:10.1177/1077800405284363

GELDER, T. V. (2005). Teaching critical thinking: Some lessons from cognitive science. College Teaching, 53, 1, 41-46. doi:10.2307/27559216

JARVIS, P. (2010). Adult education and lifelong learning: Theory and practice (4th ed.). London, UK: Routledge. 
JONES, M. (2009). Transformational learners: Transformational teachers. Australian Journal of Teacher Education, 34, 2, 15-27.

JUTRAS, P. J. (2006). The benefits of adult piano study as self-reported by selected adult piano students (Doctoral dissertation). Retrieved from ProQuest Dissertations and Theses database. (UMI No. 3095363).

KELLER, J. M. (2009). Motivational design for learning and performance: The ARCS model approach. New York, NY: Springer.

KITSANTAS, A., REISER, R. A. \& DOSTER, J. (2004). Developing self-regulated learners: Goal setting, self-evaluation, and organizational signals during acquisition of procedural skills. The Journal of Experimental Education, 72, 4, 269-287. doi:10.3200/JEXE.72.4.269-287

KNOWLES, M. S., HOLTON, E. F. III \& SWANSON, R. A. (2011). The adult learner: The definitive classic in adult education and human resource development (7th ed.). London, UK: Elsevier.

LANKSHEAR, C. \& KNOBEL, M. (2004). A handbook for teacher research: From design to implementation. Maidenhead, England: Open University Press.

LEHMANN, A. C., SLOBODA, J. A. \& WOODY, R. H. (2007). Psychology for musicians: Understanding and acquiring the skills. Oxford, UK: Oxford University Press.

LEIPER, T. (2012). The impact of critical reflection on a private practice singing teacher's thinking (Doctoral dissertation). Retrieved from http://theses.gla.ac.uk/3417

MACDONALD, R., HARGREAVES, D. J. \& MIELL, D. (2012). Musical identities. In S. Hallam, I. C. Derek \& M. Thaut (Eds.), Oxford handbook of music psychology.

http://www.oxfordhandbooks.com/view/10.1093/oxfordhb/9780199298457.00 1.0001/oxfordhb-9780199298457-e-043: Oxford.

MAEHR, M. L., PINTRICH, P. R. \& LINNENBRINK, E. A. (2002). Motivation and achievement. In R. Colwell \& C. P. Richardson (Eds.), The new handbook of research on music teaching and learning (pp. 348-372). New York, NY:

Oxford University Press.

MARIS, B. E. (2000). Making music at the piano: Learning strategies for adult students. Oxford, UK: Oxford University Press.

MCALLISTER, L. S. (2008). Evaluating teaching effectiveness in music. The American Music Teacher, 58, 3, 14-17.

MCCORMICK, J. \& MCPHERSON, G. (2003). The role of self-efficacy in a musical performance examination: An exploratory structural equation analysis. Psychology of Music, 31, 1, 37-51. doi:10.1177/0305735603031001322

MCPHERSON, G. E. \& ZIMMERMAN, B. J. (2002). Self-regulation of musical learning. In R. Colwell \& C Richardson (Eds.), The new handbook of research on music teaching and learning: A project of the Music Educators National Conference (pp. 327-347). Oxford, UK: Oxford University Press.

MEZIROW, J. (1991). Transformative dimensions of adult learning. San Francisco, CA: Jossey-Bass. 
MEZIROW, J. (2003). Transformative learning as discourse. Journal of Transformative Education, 1, 1, 58-63.

MIZOK-TAYLOR, R. J. (2008). Promoting self-directed learning in adult piano instruction (Doctoral dissertation). Retrieved from ProQuest Dissertations \& Theses database. (UMI No. 3376459).

NIELSEN, S. G. (2004). Strategies and self-efficacy beliefs in instrumental and vocal individual practice: A study of students in higher music education. Psychology of Music, 32, 4, 418-431. doi:10.1177/0305735604046099

RENWICK, J. \& REEVE, J. (2012). Supporting motivation in music education. In G. McPherson \& G. Welch (Eds.), The Oxford handbook of music education (Vol. 1, pp. 143-162). Oxford, UK: Oxford University Press.

RICHARDSON, V. (1994). Conducting research on practice. Educational Researcher, 23, 5, 5-10. doi:10.3102/0013189X023005005

RINALDO, V. \& DENIG, S. (2009). A constructivist approach to learning music: What role, if any, does active engagement play in the learning process? Retrieved from http://www.jpacte.org/uploads/9/0/0/6/9006355/2009-1rinaldo_denig.pdf

RYBAK, C. A. (1995). Older adults and "flow": Investigating optimal experience in selected music leisure activities (Doctoral thesis, Arizona State University). ProQuest Dissertations Publishing, 9611711.

SCHUNK, D. H. (2012). Attributions as motivators of self-regulated learning. In B. J. Zimmerman \& D. H. Schunk (Eds.), Motivation and self-regulated learning: Theory, research, and applications (pp. 245-266). New York, NY: Lawrence Erlbaum Associates.

SMELTZER, R. C. (n.d.). The adult piano student as an adult learner: Exploring motivation and retention. Retrieved from http://web.utk.edu/ rsmeltze/Additional\%20Coursework/EP525/SmeltzerAdul tPianoWiki.pdf

SWENSON, T. S. (2006). Profiles of career-aged keyboard students: Attitudes, preferences, and demographics (Doctoral dissertation). Retrieved from ProQuest database. (UMI No. 3211367)

TAYLOR, A. (2011). Older amateur keyboard players learning for self-fulfilment. Psychology of Music, 39, 3, 345-363.

TAYLOR, A. \& HALLAM, S. (2008). Understanding what it means for older students to learn basic musical skills on a keyboard instrument. Music Education Research, 10, 2, 285-306.

TAYLOR, E. W. (2008). Transformative learning theory. New Directions for Adult and Continuing Education, 119, 5-15.

THORNTON, D. H. (2010). Adult music engagement: Perspectives from three musically engaged cases (Doctoral dissertation). Retrieved from ProQuest Dissertations and Theses database. (UMI No. 3442897).

USZLER, M. \& UPITIS, R. (2000). The adult student. In M. Uszler, S. Gordon \& S. M. Smith (Eds.), The well-tempered keyboard teacher (pp. 55-78). Belmont, CA: Schirmer. 
VANCOUVER, J. B., MORE, K. M. \& YODER, R. J. (2008). Self-efficacy and resource allocation: Support for a nonmonotonic, discontinuous model. Journal of Applied Psychology, 93, 1, 35-47.

WEINER, B. (2010). The development of an attribution-based theory of motivation: A history of ideas. Educational Psychologist, 45, 1, 28-36.

WIEZBICKI-STEVENS, K. (2009). Metacognition: Developing self-knowledge through guided reflection (Doctoral dissertation). Retrieved from http://scholarworks.umass.edu/open_access_dissertations/126/

WRISTEN, B. (2006). Demographics and motivation of adult group piano students. Music Education Research, 8, 3, 387-406.

ZIMMERMAN, B. J. \& SCHUNK, D. H. (2012). Motivation: An essential dimension of self-regulated learning. In B. J. Zimmerman \& D. H. Schunk (Eds.), Motivation and self-regulated learning: Theory, research, and applications (pp. 1-30). New York, NY: Lawrence Erlbaum Associates. 


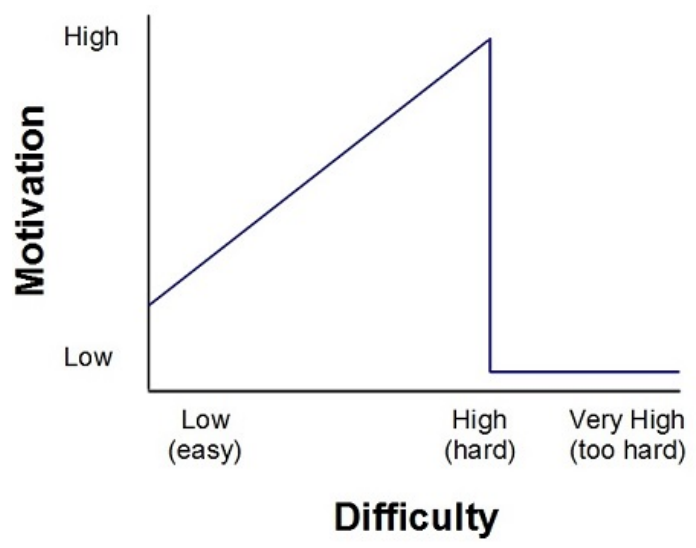

Figure 1. Discontinuous model of motivation (Amin, n.d.).

Table 1. Student Participant Background

\begin{tabular}{|c|c|c|c|c|c|}
\hline $\begin{array}{l}\text { First } \\
\text { name }\end{array}$ & $\begin{array}{l}\text { Prior } \\
\text { learning } \\
\text { as a } \\
\text { child }\end{array}$ & $\begin{array}{l}\text { Age } \\
\text { bracke } \\
\text { t }\end{array}$ & $\begin{array}{l}\text { Musical level } \\
\text { (AMEB }{ }^{1} \\
\text { grade } \\
\text { equivalent) }\end{array}$ & $\begin{array}{l}\text { Musical } \\
\text { tastes }\end{array}$ & Musical aspirations \\
\hline Cathryn & Yes & $45-49$ & Grade 4 & Classical & $\begin{array}{l}\text { To play the } \\
\text { sophisticated and } \\
\text { advanced repertoire } \\
\text { that inspires her to } \\
\text { what she deems as a } \\
\text { musically gratifying } \\
\text { standard }\end{array}$ \\
\hline Anne & Yes & $70-74$ & Grade 3 & Classical & $\begin{array}{l}\text { To play advanced } \\
\text { pieces from the } \\
\text { composers she enjoys } \\
\text { (Mozart/Haydn) }\end{array}$ \\
\hline Graham & No & $75-79$ & Preliminary & Jazz & $\begin{array}{l}\text { To play to the highest } \\
\text { standard that is } \\
\text { possible for him to } \\
\text { reach } \\
\text { To emulate 'The } \\
\text { Greats' (the pianists of } \\
\text { the } 1920 \text { s to } 1950 \mathrm{~s} \\
\text { that he admires) }\end{array}$ \\
\hline Derek & No & $65-69$ & Preliminary & $\begin{array}{l}\text { Classical } \\
\text { Popular }\end{array}$ & $\begin{array}{l}\text { To complete all } \\
\text { classical AMEB } \\
\text { practical examinations } \\
\text { on piano }\end{array}$ \\
\hline
\end{tabular}

${ }^{1}$ Australian Music Examination Board 
